\title{
Assessment of Water Quality of Wastewaters of Bahr El-Baqar, Bilbies and El-Qalyubia Drains in East Delta, Egypt for Irrigation Purposes
}

\author{
M.K. Abdel-Fattah and A.M. Helmy \\ Soil Science Department, Faculty of Agriculture, Zagazig \\ University, Sharqia, Egypt.
}

\begin{abstract}
SAMPLES of agricultural drainage water were collected monthly $\checkmark$ from the drains of Bahr El-Baqar, Bilbies and El-Qalyubia, East Delta, Egypt for one year from October 2013 to September 2014 to evaluate water quality and suitability for irrigation purpose. According to the USDA water was classified as class high salinity low sodicity (C3S1) which cannot be used on soils with restricted drainage. With adequate drainage and special management for salinity control and plants with good tolerance to salinity, the water could be used for irrigation. According to Gupta classification, water of Bahr El-Baqar drain is classified as low salinity with no sodicity $(\mathrm{C} 2 \mathrm{~S} 0)$ while water of Bilbies and El-Qalyubia drains is classified as normal water with non-sodic (C1S0) and can be used for irrigation to most crops on most soils. Water of the three drains are suitable for most crops except the salinity sensitive ones and can be used to irrigate all soils except the very heavy textured, with impeded drainage. These waters do not have any problems regarding sodicity.
\end{abstract}

Keyword : Bahr El-Baqar, Bilbies, El-Qalyubia, Drains, Water quality, Egypt .

Water shortages have become increasingly serious problems in Egypt due to the prevailing arid and semi-arid climate on one side and the high quantities of water requirement for the agricultural expansion and soil reclamation on the other side. In Egypt limited water resources necessitates the reuse of agricultural drainage water in irrigation. However, there are some concerns about the quality of such waters. Utilization in irrigation of untreated or partially treated waste waters can give rise to pollution problems in surface and ground waters as well as soils and plants. Pollution of drainage water and water resources with heavy metals is one of the most serious problems (UNEP, 1991 and Da Costa et al., 1996).

About 12 billion $\mathrm{m}^{3}$ of water are drained yearly, and only about 4.2 billion $\mathrm{m}^{3}$ are reused, particularly in the Nile Delta about 420000 ha were irrigated with such waters (Abu, 2011). The Reuse of this drainage water without suitable treatment may cause adverse effects on soil and crop. One of the most polluted drains in Egypt is Bahr El-Baqar drain (Abdel-Shafy and Aly, 2002). The Bahr El-Baqar coordinates are $31^{\circ} 7^{\prime} 0^{\prime \prime} \mathrm{N}$ and $32^{\circ} 6^{\prime} 0^{\prime \prime} \mathrm{E}$. Bahr El-Baqar is located in the eastern part of the Nile Delta and runs for about $170 \mathrm{~km}$ from Cairo to Lake Manzala. Arable lands irrigated by water of this drain and its tributaries are 
about 317,000 ha. The main drain collects water from the two secondary drains of Bilbeis and Qalyubya, which collect water from the two drains, of Gabal El Asfar and Shebeen (DRI, 2005). Bahr El-Baqar drain receives untreated waste water starting from east of Cairo, at El-Gebel El-Asfar and then joined by the Belbeis drain, down to Qalubiya drain. The length of the main drain is $170 \mathrm{~km}$ with a depth of 1 to 3 meter and width is about 30 to 70 meter (Taha et al., 2004). El-Manzala Lake receives and carries the greatest part of wastewater (about 3 million $\mathrm{m}^{3}$ per year) into Lake, which passed through Qalubyia, Sharkia, Ismailia and Port Said regions. Four main sources of pollutants cause deterioration in Bahr El-Baqar drain. Waste waters of the industrial activities in region including metal, food processing, detergents and soaps manufacturing, textile and paper production are discharges into the drain. These soils receive many pollutants, such as heavy metals including lead, cadmium, nickel, and mercury (Park and Shin, 2006). Prolonged use of such drain water for irrigation leads to accumulation of heavy metals in Port-Said soils (Ali et al., 1993). Water quality, chemical composition, and hazardous effects on Lake Manzala water and living organisms caused by Bahr El-Baqar drain water were studied by Rashed \& Holmes (1984), Khalil (1985) and Ezzat (1989). The discharge of industrial, agricultural and municipal wastewaters in Bahr El-Baqar drain led to contamination of soils, which irrigated by water of this drain. Saad (1997) concluded that $58 \%$ of the total drainage water of Bahr El-Baqar drain comes from agricultural drainage, $2 \%$ from industrial drainage and $40 \%$ from domestic and commercial drainage. The present study focuses on the quality of Bahr El-Baqar, Bilbies and El-Qalyubia Drains in Eastern Delta for agricultural irrigation.

\section{Materials and Methods}

Water samples were collected monthly from Bahr El-Baqar, Bilbies and ElQalyubia drains, which are located in East Eastern Delta, Egypt for one year from October 2013 to September 2014 to evaluate water quality for use in agricultural irrigation. Samples were collected from the beginning, middle and end of each drain. The size of the sample was about 4 liters. Precaution was taken to avoid sample contamination. Samples were filtered immediately and stored in plastic bottles at $4^{\circ}$ Celsius until analysis. Samples were analyzed in the laboratory for the major ions chemistry employing standard method (APHA, 1995). Calcium $\left(\mathrm{Ca}^{2+}\right)$ and magnesium $\left(\mathrm{Mg}^{2+}\right)$ were determined titrimetrically using standard EDTA, chloride $\left(\mathrm{Cl}^{-}\right)$by standard $\mathrm{AgNO}_{3}$ titration, bicarbonate $\left(\mathrm{HCO}_{3}{ }^{-}\right)$by titration with $\mathrm{HCl}$, sodium $\left(\mathrm{Na}^{+}\right)$and potassium $\left(\mathrm{K}^{+}\right)$by flame photometry. $\mathrm{EC}$ and $\mathrm{pH}$ were measured directly insitu.

Criteria for judging the validity of water were soluble sodium percentage (SSP), sodium adsorption ratio (SAR), exchangeable sodium percentage (ESP), sodium to calcium activity ratio (SCAR), residual sodium carbonate (RSC), residual sodium bicarbonate (RSBC), permeability index (PI), potential salinity (PS), Kelly ratio (KR) and magnesium adsorption ratio (MAR). Further, the results of the analyses were interpreted using graphical representations like

Egypt. J. Soil Sci. 55, No. 3 (2015) 
United States Salinity Laboratory (USSL), Wilcox Diagram, Piper Diagram and Doneen plots.

\section{Soluble sodium percentage (SSP)}

High sodium ion concentration in soil can take a toll on internal drainage patterns in soil as release of calcium and magnesium ions are facilitated due to absorption of sodium by clay particles. SSP was calculated using the following equation :

$$
\mathrm{SSP}=\frac{\mathrm{Na}^{+}}{\mathrm{Na}^{+}+\mathrm{K}^{+}+\mathrm{Ca}^{+2}+\mathrm{Mg}^{+2}} \times 100 \quad \text { (Todd, 1980) }
$$

where, concentrations of all ions have been expressed in $\mathrm{mmol}_{\mathrm{c}} / \mathrm{L}$. Water with SSP less than 60 is safe with little sodium accumulations that will cause a breakdown of the soil's physical properties (Fipps, 1998).

\section{Sodium adsorption ratio (SAR)}

Sodium adsorption ratio is a measure of the sodicity of the soil. The SAR was calculated using the following equation:

$$
\mathrm{SAR}=\mathrm{Na}^{+} /\left(\left[\mathrm{Ca}^{2+}+\mathrm{Mg}^{2+}\right] / 2\right)^{1 / 2}(\text { USDA, 1954) }
$$

where, concentrations of all ions have been expressed in $\mathrm{mmol}_{\mathrm{c}} / \mathrm{L}$. The SAR classes include, low, S1 (<10); medium, S2 (10-18); high, S3 (18-26); and very high, S4 (>26).

Sodium to calcium activity ratio (SCAR)

SCAR can be calculated according to the relationships presented by Gupta (1990) and presented in the following equation where all ions in $\mathrm{mmol}_{\mathrm{c}} / \mathrm{L}$.

$$
\mathrm{SCAR}=\mathrm{Na}^{+} /\left(\mathrm{Ca}^{2+}\right)^{1 / 2}
$$

On the basis of SAR/SCAR, the irrigation waters may be classified in six classes of sodicity, Non-sodic water, S0 (<5); Normal water, S1 (5-10); Low sodicity water, S2 (10-20); Medium sodicity water, S3 (20-30), High sodicity water, S4 (30-40) and Very high sodicity water, S5 (>40).

\section{Residual sodium carbonate (RSC)}

Excess carbonate and bicarbonate ions over calcium and magnesium ions lead to presence of sodium carbonate, its ion is higher than calcium ions which is considered undesirable, because after evaporation leads to sodicity. The equation is as follows:

$$
\mathrm{RSC}=\left(\mathrm{CO}_{3}{ }^{=}+\mathrm{HCO}_{3}^{-}\right)-\left(\mathrm{Ca}^{2+}+\mathrm{Mg}^{2+}\right)(\mathrm{USDA}, 1954)
$$

where concentrations of all ions have been expressed in $\mathrm{mmol}_{\mathrm{c}} \mathrm{L}^{-1}$. RSC classes are no-hazard $(<1.25)$, medium hazard (1.25-2.5) and extreme hazard $(>2.5)$. 
Residual sodium bicarbonate (RSBC)

Since carbonate ions do not occur very frequently in appreciable concentrations and as bicarbonate ions do not precipitate magnesium ions, Gupta suggested that alkalinity hazard could be determined through this parameter, which is calculated as follows:

$$
\mathrm{RSBC}=\mathrm{HCO}_{3}^{-}-\mathrm{Ca}^{2+} \text { (ions concentration in } \mathrm{mmol}_{\mathrm{c}} \mathrm{L}^{-1} \text { ) }
$$

Based on RSC/ RSBC ratio there are six alkalinity classes as the follows: non-alkaline water, A0 (negative value); normal water, A1 (0); low alkalinity water, A2 (2.5); medium alkalinity water, A3 (2.5-5); high alkalinity water, A4 (5-10) and very high alkalinity water, A5 (>10).

Permeability index $(P I)$

The PI given by the following formula (USDA, 1954 and Doneen, 1964):

$$
\mathrm{PI}=\frac{\mathrm{Na}^{+}+\left(\mathrm{HCO}_{3}\right)^{1 / 2}}{\mathrm{Na}^{+}+\mathrm{Ca}^{2+}+\mathrm{Mg}^{2+}} \times 100
$$

where, concentrations of all ions have been expressed in $\mathrm{mmol}_{c} \mathrm{~L}^{-1}$. The PI classification is as follows: Excellent $(>75 \%)$, Good $(25-75 \%)$ and Unsuitable $(<25 \%)$ (Al-Amry, 2008).

\section{Potential salinity (PS)}

Potential salinity (PS) was defined as the chloride plus half of the sulfate concentration (Doneen, 1962 and Gupta, 1990).

$$
\mathrm{PS}=\mathrm{Cl}^{-}+1 / 2 \mathrm{SO}_{4}{ }^{=}\left(\text {ion concentration in } \mathrm{mmol}_{\mathrm{c}} \mathrm{L}^{-1}\right)
$$

The PS classification is as follows: permissible 5-20, 3-15 and 3-7, for soils of good, medium and low permeability, respectively (Gupta, 1990).

\section{Kelly's index (KI)}

Kelly's index is used for the classification of water for irrigation purposes. Sodium measured against calcium and magnesium is considered for calculating this parameter. A KI $(>1)$ indicates an excess level of sodium in waters (Kelly, 1940). Therefore, waters with a KI $(<1)$ is suitable for irrigation, while those with greater ratio are unsuitable (Sundaray et al., 2009). KI is calculated by using the formula; where all the ions are expressed in $\mathrm{mmol}_{\mathrm{c}} / \mathrm{L}$.

$$
\left.\mathrm{KI}=\mathrm{Na}^{+} /\left(\mathrm{Ca}^{2+}+\mathrm{Mg}^{2+}\right) \text { (ion concentration in } \mathrm{mmol}_{\mathrm{c}} \mathrm{L}^{-1}\right)
$$

Magnesium adsorption ratio (MAR)

$\mathrm{Ca}^{2+}$ and $\mathrm{Mg}^{2+}$ maintain a state of equilibrium in most waters (Hem, 1985). High $\mathrm{Mg}^{2+}$ in adversely affects soil rendering it alkaline (Kumar et al., 2007). The magnesium hazard of irrigation water is evaluated using the MAR (Paliwal,

Egypt. J. Soil Sci. 55, No. 3 (2015) 
$1972)$ and is calculated by the following equation. The MAR classification is as follows: safe $(<50)$ and having $\mathrm{Mg}^{2+}$ hazard $(>50)$

$$
\mathrm{MAR}=\left(\mathrm{Mg}^{2+} \times 100\right) /\left(\mathrm{Ca}^{2+}+\mathrm{Mg}^{2+}\right)
$$

\section{Results and Discussion}

Water $\mathrm{pH}$

The main use of $\mathrm{pH}$ in a water analysis is for detecting abnormal waters. The normal $\mathrm{pH}$ range for irrigation water is from 6.5 to 8.4. An abnormal value is a warning that the water needs further evaluation. Irrigation water with a $\mathrm{pH}$ outside the normal range may cause a nutritional imbalance or may contain a toxic ion (FAO, 1985). Table 1 shows that $\mathrm{pH}$ of water is within the acceptable range every month, as there was no much variations.

\section{Salinity hazard}

Table 1 shows the ionic composition of water. Water of Bahr El-Baqar drains was highly saline. The EC ranged from 7.33 to $7.70 \mathrm{mS} / \mathrm{cm}$ being of highly saline category. The highest EC was during the month of February, while the lowest EC was during the month of January. As for water of Bilbies drain, it was of low to medium salinity. It ranged from 1.05 to $1.95 \mathrm{mS} / \mathrm{cm}$. The lowest was in November and the highest was in February. El-Qalyubia Drain showed values of 1.05 and $1.41 \mathrm{mS} / \mathrm{cm}$ during the months of May and January, respectively.

According to USDA (1954), salinity classes range from low to very high. Water in Bahr El-Baqar, Bilbies and El-Qalyubia drains is of high salinity (C3), which should not be used on soils with restricted drainage and if used, special management for salinity control should be done and salt tolerant plants should be used.

According to Gupta classification (Gupta, 1979a, b) the irrigation waters are of salinity hazard. Water in Bilbies and El-Qalyubia drains is considered normal waters (C-1) and can be used for irrigation with most crops on most soils with little likelihood that soil salinity to develop. Large areas of citrus trees, (salinity sensitive plants) are irrigated for many years with waters having EC $1.5 \mathrm{dS} / \mathrm{m}$, with small leaching with relatively high $\mathrm{Ca}^{2+}$ and low $\mathrm{Cl}^{-}$, while water of Bahr El-Baqar drain is considered of low salinity (C-2) and can be used if moderate leaching. Most crops irrigated by such water are horticultural and mostly leguminous. These waters do not have high sodicity problem (Gupta, 1990).

Relative abundance of cations in water of Bahr El-Baqar, Bilbies and ElQalyubia Drain was $\mathrm{Na}^{+}>\mathrm{Ca}^{2+}>\mathrm{Mg}^{2+}>\mathrm{K}^{+}$, respectively. Regarding anion abundance for Bahr El-Baqar the pattern was $\mathrm{Cl}^{-}>\mathrm{HCO}_{3}{ }^{-}>\mathrm{SO}_{4}{ }^{-}>\mathrm{CO}_{3}{ }^{-}$. The pattern for Bilbies was $\mathrm{Cl}^{-}>\mathrm{HCO}_{3}{ }^{\circ}>\mathrm{SO}_{4}{ }^{\circ}>\mathrm{CO}_{3}{ }^{\circ}$. The pattern for El-Qalyubia was $\mathrm{SO}_{4}{ }^{-}>\mathrm{Cl}^{-}>\mathrm{HCO}_{3}{ }^{-}>\mathrm{CO}_{3}{ }^{=}$. 
TABLE 1. Chemical analysis of waters of drains at different months (annual average of the three drains).

\begin{tabular}{|c|c|c|c|c|c|c|c|c|c|c|}
\hline \multirow{2}{*}{ Month } & \multirow[b]{2}{*}{ pH } & \multirow{2}{*}{$\begin{array}{c}\mathrm{EC} \\
\mathrm{mS} / \mathrm{cm}\end{array}$} & \multicolumn{4}{|c|}{ Cations $\left[\operatorname{mmol}_{\mathrm{c}} \mathrm{L}^{-1}\right]$} & \multicolumn{4}{|c|}{ Anions $\left[\operatorname{mmol}_{c} L^{-1}\right]$} \\
\hline & & & $\mathrm{Ca}^{+2}$ & $\mathrm{Mg}^{+2}$ & $\mathrm{Na}^{+}$ & $\mathbf{K}^{+}$ & $\mathrm{CO}_{3}=$ & $\mathrm{HCO}_{3}^{-}$ & $\mathrm{Cl}^{-}$ & $\mathrm{SO}_{4}=$ \\
\hline \multicolumn{11}{|c|}{ Bahr El-Baqar Drain (D1) } \\
\hline Oct & 7.43 & 1.43 & 4.23 & 2.03 & 5.90 & 0.43 & 0.30 & 4.27 & 4.03 & 4.00 \\
\hline Nov & 7.43 & 1.67 & 3.83 & 3.33 & 8.67 & 0.43 & 0.37 & 4.83 & 7.33 & 3.73 \\
\hline Dec & 7.40 & 1.60 & 5.03 & 4.17 & 5.43 & 0.37 & 0.30 & 5.67 & 5.77 & 3.27 \\
\hline Jan & 7.33 & 1.57 & 3.93 & 3.30 & 6.10 & 0.53 & 0.27 & 5.13 & 4.67 & 3.80 \\
\hline Feb & 7.70 & 2.00 & 4.13 & 4.17 & 7.63 & 0.60 & 0.37 & 6.33 & 5.27 & 4.57 \\
\hline Mar & 7.37 & 1.47 & 4.07 & 2.83 & 6.53 & 0.50 & 0.50 & 5.37 & 4.47 & 3.60 \\
\hline Apr & 7.47 & 1.60 & 3.80 & 3.60 & 8.07 & 0.40 & 0.43 & 4.63 & 5.87 & 4.93 \\
\hline May & 7.47 & 1.47 & 3.87 & 3.57 & 5.27 & 0.47 & 0.53 & 4.33 & 5.00 & 3.30 \\
\hline Jun & 7.50 & 1.47 & 6.70 & 2.40 & 5.20 & 0.43 & 0.27 & 4.47 & 7.27 & 2.73 \\
\hline Jul & 7.50 & 1.60 & 3.63 & 2.93 & 8.33 & 0.37 & 0.30 & 5.03 & 5.70 & 4.23 \\
\hline Aug & 7.47 & 1.33 & 3.57 & 2.53 & 6.40 & 0.37 & 0.30 & 5.53 & 5.07 & 1.97 \\
\hline Sep & 7.43 & 1.27 & 4.10 & 2.20 & 5.13 & 0.47 & 0.23 & 5.07 & 3.97 & 2.63 \\
\hline$L S D 0.05$ & $n s$ & $n s$ & 1.21 & $n s$ & $n s$ & $n s$ & $n s$ & $n s$ & $n s$ & $n s$ \\
\hline \multicolumn{11}{|c|}{ Bilbies Drain (D2) } \\
\hline Oct & 7.45 & 1.40 & 4.35 & 2.05 & 6.05 & 0.40 & 1.10 & 4.00 & 3.55 & 4.20 \\
\hline Nov & 7.55 & 1.05 & 3.00 & 1.55 & 5.10 & 0.40 & 1.30 & 3.25 & 3.05 & 2.45 \\
\hline Dec & 7.25 & 1.55 & 4.75 & 1.20 & 4.85 & 0.28 & 0.90 & 3.85 & 5.25 & 1.08 \\
\hline Jan & 7.20 & 1.36 & 6.95 & 1.75 & 6.25 & 0.65 & 0.40 & 6.30 & 4.05 & 4.85 \\
\hline Feb & 7.45 & 1.95 & 8.05 & 3.05 & 6.81 & 0.58 & 0.68 & 4.70 & 8.35 & 4.76 \\
\hline Mar & 7.60 & 1.37 & 3.45 & 2.05 & 6.45 & 0.52 & 0.70 & 4.80 & 3.40 & 3.57 \\
\hline Apr & 8.15 & 1.46 & 3.60 & 2.50 & 5.10 & 0.50 & 2.05 & 3.10 & 3.40 & 3.15 \\
\hline May & 8.15 & 1.25 & 3.65 & 2.50 & 4.85 & 0.33 & 2.95 & 2.15 & 3.35 & 2.88 \\
\hline Jun & 7.90 & 1.15 & 3.53 & 1.55 & 5.05 & 0.35 & 1.75 & 2.10 & 3.80 & 2.83 \\
\hline Jul & 7.55 & 1.35 & 3.85 & 1.55 & 4.05 & 0.30 & 1.70 & 4.20 & 3.55 & 0.30 \\
\hline Aug & 8.05 & 1.30 & 3.79 & 1.35 & 4.55 & 0.28 & 2.55 & 2.15 & 3.65 & 1.62 \\
\hline Sep & 8.15 & 1.20 & 4.05 & 1.58 & 4.40 & 0.23 & 1.95 & 2.80 & 3.40 & 2.10 \\
\hline$L S D 0.05$ & 0.19 & 0.04 & 0.13 & 0.12 & 0.12 & 0.05 & 0.44 & 0.21 & 0.33 & 0.40 \\
\hline \multicolumn{11}{|c|}{ El-Qalyubia drain (D3) } \\
\hline Oct & 7.35 & 1.40 & 5.55 & 4.60 & 4.35 & 0.25 & 0.95 & 4.50 & 6.10 & 3.20 \\
\hline Nov & 7.65 & 1.28 & 3.95 & 3.20 & 5.40 & 0.30 & 1.45 & 4.35 & 4.50 & 2.55 \\
\hline Dec & 7.80 & 1.24 & 3.70 & 1.75 & 6.40 & 0.30 & 1.70 & 2.80 & 3.45 & 4.20 \\
\hline Jan & 7.30 & 1.34 & 3.70 & 2.15 & 4.95 & 0.44 & 1.35 & 2.45 & 3.65 & 3.79 \\
\hline Feb & 7.45 & 1.37 & 4.25 & 2.65 & 5.80 & 0.35 & 0.70 & 2.80 & 3.95 & 5.60 \\
\hline Mar & 7.50 & 1.31 & 3.35 & 3.00 & 5.75 & 0.30 & 0.50 & 3.05 & 3.95 & 4.90 \\
\hline Apr & 7.45 & 1.10 & 3.60 & 1.30 & 3.75 & 0.40 & 0.65 & 2.95 & 3.70 & 1.75 \\
\hline May & 7.35 & 1.05 & 3.95 & 1.20 & 4.70 & 0.35 & 0.70 & 3.95 & 3.00 & 2.55 \\
\hline Jun & 7.40 & 1.41 & 2.75 & 2.45 & 6.50 & 0.50 & 0.90 & 3.75 & 3.95 & 3.60 \\
\hline Jul & 7.30 & 1.26 & 3.05 & 2.50 & 5.55 & 0.30 & 1.10 & 3.40 & 3.25 & 3.65 \\
\hline Aug & 7.50 & 1.30 & 3.00 & 4.35 & 5.20 & 0.40 & 0.55 & 3.05 & 3.50 & 5.85 \\
\hline Sep & 7.85 & 1.13 & 2.50 & 2.55 & 2.25 & 0.40 & 0.75 & 2.50 & 2.65 & 1.80 \\
\hline LSD0.05 & 0.35 & $n s$ & 0.65 & 0.93 & 1.34 & $n s$ & $n s$ & $n s$ & 1.07 & 2.45 \\
\hline D1 & 7.46 & 1.54 & 4.24 & 3.09 & 6.56 & 0.45 & 0.35 & 5.06 & 5.37 & 3.56 \\
\hline D2 & 7.70 & 1.37 & 4.42 & 1.89 & 5.29 & 0.40 & 1.50 & 3.62 & 4.07 & 2.82 \\
\hline D3 & 7.49 & 1.27 & 3.61 & 2.64 & 5.05 & 0.36 & 0.94 & 3.30 & 3.80 & 3.62 \\
\hline LSD0.05 & 0.12 & 0.12 & 0.28 & 0.36 & 1.03 & $n s$ & 0.32 & 0.41 & $n s$ & 0.46 \\
\hline
\end{tabular}

Egypt. J. Soil Sci. 55, No. 3 (2015) 


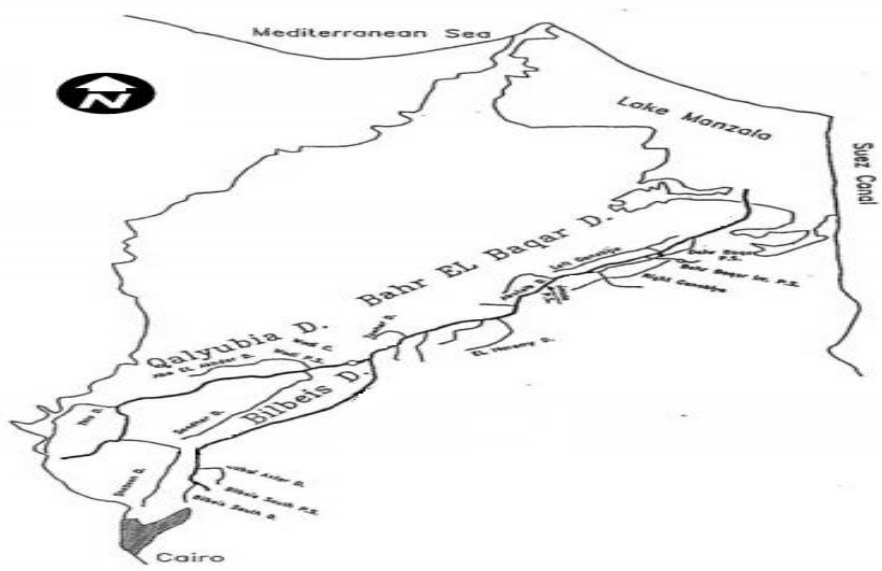

Fig. 1. Study Area (Bahr El-Baqar, Bilbies and El-Qalyubia drains in Eastern Delta).

Piper (1944) has developed a form of trilinear diagram, which is an effective tool in segregating analysis data with respect to sources of the dissolved constituents in water, modifications in the character of water as it passes through an area and related geochemical problems. A Piper trilinear diagram is a graphical representation classifying water based on the dominant presence of cations and anions (Fig. 2). According to such diagram waters can be assessed in 3 types: Fresh type, sulfate type and saline type. Piper diagram classified all water samples into "Mixed $\mathrm{Ca}^{2+}-\mathrm{Mg}_{2}{ }^{+}$ $\mathrm{Cl}^{-}$Type" (Fig. 2). No change in waters was recorded suggesting ionic stability with respect to $\mathrm{Na}^{+}, \mathrm{K}^{+}, \mathrm{Ca}^{2+}, \mathrm{Mg}^{2+}, \mathrm{HCO}_{3}^{-}, \mathrm{Cl}^{-}$and $\mathrm{SO}_{4}{ }^{2-}$.
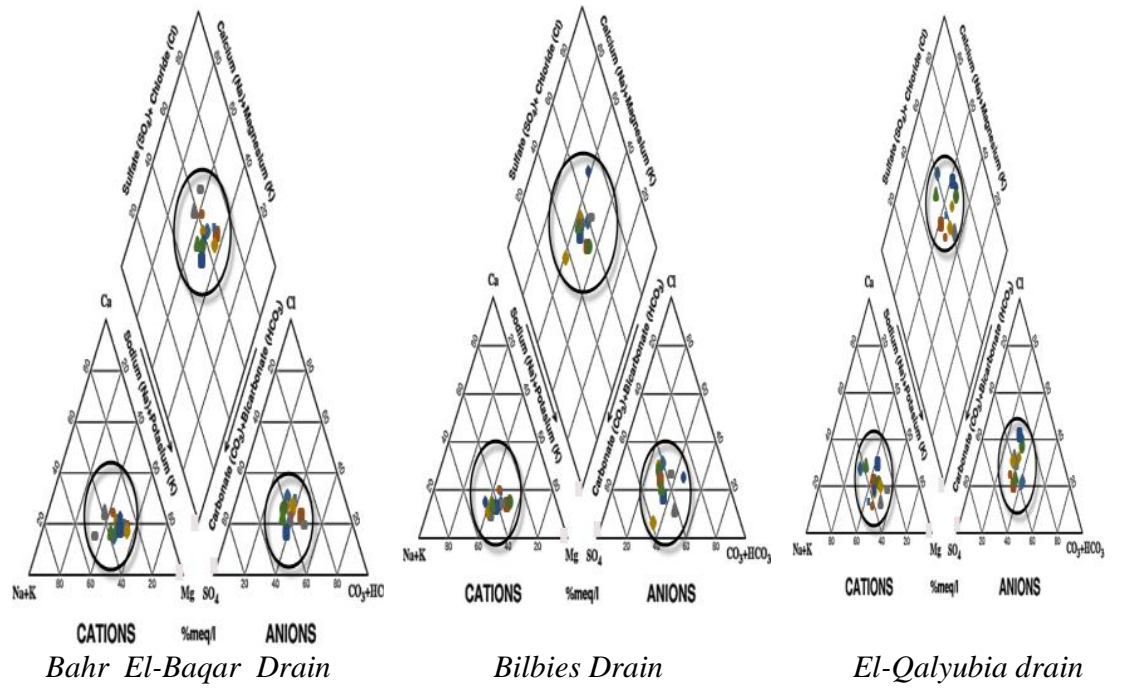

Fig. 2. Classification of waters during a year on the diagram of Piper (1944). 
Sodicity hazard

Table 2 shows soluble sodium percentage (SSP), sodium adsorption ratio (SAR), sodium to calcium activity ratio (SCAR), residual sodium carbonate (RSC), residual sodium bicarbonate (RSBC), permeability index (PI), potential salinity (PS), Kelly ratio (KR) and magnesium adsorption ratio (MAR).

TABLE 2. Quality parameters of Bahr El-Baqar, Bilbies and El-Qalyubia Drains.

\begin{tabular}{|c|c|c|c|c|c|c|c|c|c|c|c|c|}
\hline Month & SSP & SAR & SCAR & $\begin{array}{l}\text { SAR/ } \\
\text { SCAR }\end{array}$ & RSC & RSBC & PI & PS & KR & MAR & $\begin{array}{l}\text { USDA } \\
\text { Class }\end{array}$ & $\begin{array}{l}\text { ICAR } \\
\text { Class }\end{array}$ \\
\hline \multicolumn{13}{|c|}{ Bahr El-Bagar Drain (D1) } \\
\hline Oct & 46.89 & .35 & 2.87 & 1.17 & -1.70 & 0.03 & 65.52 & 6.03 & 0.95 & 32.11 & C3S1 & C1S0 \\
\hline Nov & 50.18 & 4.50 & 4.51 & 1.00 & -1.97 & 1.00 & 66.32 & 9.20 & .17 & 45.89 & C3S1 & $\mathrm{C} 2 \mathrm{SO}$ \\
\hline Dec & 36.19 & 2.53 & 2.52 & 1.00 & -3.23 & 0.63 & 53.34 & 7.40 & .59 & 45.38 & C3S1 & C2SO \\
\hline Jan & 44.01 & 3.21 & 3.07 & 1.04 & -1.83 & 1.20 & 62.88 & 6.57 & 0.85 & 44.78 & C3S1 & $\mathrm{C} 2 \mathrm{SO}$ \\
\hline Feb & 46.21 & 3.76 & 3.76 & 1.00 & -1.60 & 2.20 & 63.83 & 7.55 & 0.93 & 50.07 & C3S1 & $\mathrm{C} 2 \mathrm{~S} 0$ \\
\hline Mar & 46.94 & 3.52 & 3.24 & 1.09 & -1.03 & 1.30 & 65.98 & 6.27 & .95 & 40.96 & C3S1 & C1S0 \\
\hline Apr & 49.51 & 4.16 & 4.09 & 1.02 & -2.33 & 0.83 & 64.91 & 8.33 & .07 & 48.47 & C3S1 & $\mathrm{C} 2 \mathrm{SO}$ \\
\hline May & 40.66 & 2.77 & 2.68 & 1.03 & -2.57 & 0.47 & 58.76 & 6.65 & 0.74 & 45.25 & C3S1 & C1S0 \\
\hline Jun & 35.21 & 2.44 & 2.01 & 1.21 & -4.37 & -2.23 & 51.08 & 8.63 & 0.57 & 26.00 & C3S1 & C1S0 \\
\hline Jul & 53.41 & 4.58 & 4.35 & 1.05 & -1.23 & 1.40 & 70.13 & 7.82 & .26 & 44.31 & C3S1 & $\mathrm{C} 2 \mathrm{~S} 0$ \\
\hline Aug & 49.56 & 3.68 & 3.45 & 1.07 & -0.27 & 1.97 & 69.93 & 6.05 & 1.06 & 41.85 & C3S1 & C1S0 \\
\hline Sep & 43.16 & 2.91 & 2.54 & 1.14 & -1.00 & 0.97 & 64.59 & 5.28 & 0.82 & 34.78 & C3S1 & C1S0 \\
\hline LSD0.05 & 9.15 & $n s$ & $n s$ & & 2.13 & 1.90 & 9.18 & $n s$ & $n s$ & $n s$ & & \\
\hline \multicolumn{13}{|c|}{ Bilbies Drain (D2) } \\
\hline Oct & 47.09 & 3.38 & 2.90 & 1.17 & -1.30 & -0.35 & 64.67 & 5.65 & 0.95 & 32.04 & C3S1 & C1S0 \\
\hline Nov & 50.74 & 3.38 & 2.94 & 1.15 & 0.00 & 0.25 & 71.53 & 4.28 & 1.12 & 34.08 & C3S1 & C1So \\
\hline Dec & 43.79 & 2.81 & 2.23 & 1.26 & -1.20 & -0.90 & 63.08 & 5.79 & 0.82 & 20.18 & C3S1 & $\mathrm{C} 2 \mathrm{~S} 0$ \\
\hline Jan & 40.06 & 3.00 & 2.37 & 1.26 & -2.00 & -0.65 & 58.59 & 6.48 & 0.72 & 20.11 & C3S1 & C1S0 \\
\hline Feb & 36.82 & 2.89 & 2.40 & 1.20 & -5.73 & -3.35 & 50.11 & 10.73 & 0.61 & 27.48 & C3S1 & $\mathrm{C} 2 \mathrm{~S} 0$ \\
\hline Mar & 51.72 & 3.89 & 3.47 & 1.12 & 0.00 & 1.35 & 72.30 & 5.19 & 1.17 & 37.27 & C3S1 & C1S0 \\
\hline Apr & 43.59 & 2.92 & 2.69 & 1.09 & -0.95 & -0.50 & 61.25 & 4.98 & 0.84 & 40.97 & C3S1 & C1S0 \\
\hline May & 42.81 & 2.77 & 2.54 & 1.09 & -1.05 & -1.50 & 57.42 & 4.79 & 0.79 & 40.65 & C3S1 & C1S0 \\
\hline Jun & 48.21 & 3.17 & 2.69 & 1.18 & -1.23 & -1.43 & 64.19 & 5.21 & 1.00 & 30.54 & C3S1 & C1S0 \\
\hline Jul & 41.54 & 2.46 & 2.06 & 1.19 & 0.50 & 0.35 & 64.55 & 3.70 & 0.75 & 28.68 & C3S1 & C1S0 \\
\hline Aug & 45.66 & 2.84 & 2.34 & 1.21 & -0.44 & -1.64 & 62.09 & 4.46 & 0.89 & 26.26 & C3S1 & C1S0 \\
\hline Sep & 42.92 & 2.62 & 2.19 & 1.20 & -0.88 & -1.25 & 60.58 & 4.45 & 0.78 & 28.00 & C3S1 & C1S0 \\
\hline LSD0.05 & 0.72 & 0.08 & 0.06 & & 0.36 & 0.23 & 0.93 & 0.30 & 0.03 & 1.79 & & \\
\hline \multicolumn{13}{|c|}{ El-Qalyubia Drain (D3) } \\
\hline Oct & 29.60 & 1.94 & 1.85 & $1.0 \overline{5}$ & -4.70 & -1.05 & 44.71 & 7.70 & 0.43 & 45.28 & C3S1 & C1S0 \\
\hline Nov & 42.12 & 2.87 & 2.72 & 1.06 & -1.35 & 0.40 & 59.84 & 5.78 & 0.76 & 44.28 & C3S1 & C1S0 \\
\hline Dec & 52.62 & 3.88 & 3.33 & 1.17 & -0.95 & -0.90 & 68.07 & 5.55 & 1.18 & 31.94 & $\mathrm{C} 3 \mathrm{~S} 1$ & C1S0 \\
\hline Jan & 44.08 & 2.90 & 2.59 & 1.12 & -2.05 & -1.25 & 60.26 & 5.54 & 0.85 & 36.94 & C3S1 & C1S0 \\
\hline Feb & 44.38 & 3.12 & 2.86 & 1.09 & -3.40 & -1.45 & 58.89 & 6.75 & 0.84 & 37.46 & C3S1 & C1S0 \\
\hline Mar & 46.44 & 3.23 & 3.14 & 1.03 & -2.80 & -0.30 & 61.91 & 6.40 & 0.91 & 47.06 & C3S1 & C1S0 \\
\hline Apr & 40.40 & 2.37 & 1.96 & 1.21 & -1.30 & -0.65 & 63.26 & 4.58 & 0.75 & 26.29 & C3S1 & C1S0 \\
\hline May & 44.79 & 2.89 & 2.34 & 1.24 & -0.50 & 0.00 & 67.35 & 4.28 & 0.89 & 23.34 & C3S1 & C1S0 \\
\hline Jun & 53.25 & 4.03 & 3.92 & 1.03 & -0.55 & 1.00 & 72.15 & 5.75 & 1.25 & 47.11 & C3S1 & C1S0 \\
\hline Jul & 48.71 & 3.33 & 3.19 & 1.05 & -1.05 & 0.35 & 66.61 & 5.08 & 1.00 & 45.16 & C3S1 & C1S0 \\
\hline Aug & 40.16 & 2.71 & 3.00 & 0.90 & -3.75 & 0.05 & 55.20 & 6.43 & 0.71 & 59.15 & C3S1 & C1S0 \\
\hline Sep & 29.11 & 1.41 & 1.42 & 0.99 & -1.80 & 0.00 & 52.54 & 3.55 & 0.44 & 50.35 & C3S1 & C1S0 \\
\hline LSD0.05 & \begin{tabular}{|l|}
5.87 \\
\end{tabular} & 0.71 & 0.67 & & 2.18 & $n s$ & 6.80 & 1.85 & 0.20 & 10.48 & & \\
\hline D1 & 45.16 & 3.45 & 3.26 & 1.06 & -1.93 & 0.81 & 63.11 & 7.15 & 0.91 & 41.65 & C3S1 & $\mathrm{C} 2 \mathrm{SO}$ \\
\hline$D 2$ & 44.58 & 3.01 & 2.57 & 1.17 & -1.19 & -0.80 & 62.53 & 5.48 & 0.87 & 30.52 & C3S1 & C1S0 \\
\hline D3 & 42.97 & 2.89 & 2.69 & 1.17 & -2.02 & -0.32 & 60.90 & 5.62 & 0.83 & 41.20 & C3S1 & C1S0 \\
\hline LSD0.05 & $n s$ & $n s$ & 0.54 & & 0.37 & 0.42 & $n s$ & 1.25 & $n s$ & 2.82 & & \\
\hline
\end{tabular}

SSP = Soluble sodium percentage, SAR = Sodium Adsorption Ratio, SCAR = Sodium to Calcium Activity Ratio, $\mathrm{RSC}=$ Residual Sodium Carbonate, $\mathrm{RSBC}=$ Residual Sodium Bicarbonate, PI $=$ Permeability Index, PS $=$ Potential Salinity, KR = Kelly Ratio and MAR = Magnesium Adsorption Ratio.

Egypt. J. Soil Sci. 55, No. 3 (2015) 
Soluble sodium percentage (SSP)

There were differences between months of year in all studied cases (i.e. Bahr ElBaqar, Bilbies and El-Qalyubia Drains). The highest SSP was in Bahr El-Baqar drain (45.16\%) followed by Bilbies $(44.58 \%)$ and El-Qalyubia Drains $(42.97 \%)$. The highest and the lowest SSP were in July (53.41\%) \& Jun (35.21\%) in Bahr El-Baqar, Mar (51.72\%) \& Feb (36.82\%) in Bilbies and Jun (53.25\%) \& Sep (29.11\%) in ElQalyubia. this indicates moderate degree of restriction in using these waters. The SSP values and the EC values have been plotted on the Wilcox diagram (Wilcox, 1955). The results indicate that the waters could be used for irrigation (Fig. 3).

Sodium adsorption ratio (SAR)

Table 2 shows differences between months. The highest SAR was in Bahr ElBaqar drain (3.45) followed by Bilbies (3.01) and El-Qalyubia Drains (2.89). The highest and the lowest SAR were in Jul (4.58) \& Jun (2.44) for Bahr El-Baqar, Mar (3.89) \& Jul (2.46) for Bilbies and Sep (1.41) \& Jun (4.03) for El-Qalyubia Drains, respectively. Therefore, since such values are $<10$, this indicates little restriction on the use of this water in irrigation (USDA, 1954). The classification of waters indicates that all drains have waters of high salinity-low sodicity (C3S1) according to USDA (1954) classification (Fig. 4). Thus with adequate drainage and special management for salinity control such as waters could be used for irrigation.

\section{Sodium to calcium activity ratio (SCAR)}

According to Gupta (1990) waters in the three drains were classified nonsodic water (S0) therefore they can be used for irrigation on almost all soils for all crops even those sensitive to sodium such as stone-fruit tree or wood trees. Based on the EC and the value of SAR/SCAR Bahr El-Baqar drain can be classified as C2S0 while Bilbies and El-Qalyubia drains considered C1S0 (Table 2).

Residual sodium carbonate (RSC)

According to USDA (1954) waters of three drains could be used safely for irrigation purposes since RSC values are less than 1.25.

\section{Residual sodium bicarbonate ( $R S B C)$}

According to classification of Gupta (1990), water in three drains is considered non-alkaline water, A0 and could be used on almost all soils for all crops for indefinitely long periods without any problem.

\section{Permeability index (PI)}

Waters in three drains are of good quality for irrigation purposes since PI values are lower than 75 . The analytical data is plotted on the Doneen's chart (Fig. 5). The PI ranges from $60.9 \%$ to $63.11 \%$, which comes under class-I of Doneen's chart.

\section{Potential salinity (PS)}

The PS values of the drainage water samples in the study area were 7.15, 5.48 and $5.62 \mathrm{mmol}_{\mathrm{c}} / \mathrm{L}$ for Bahr El-Baqar, Bilbies and El-Qalyubia drains, respectively. Therefore, the tested drainage water falls under recommended permissible. 

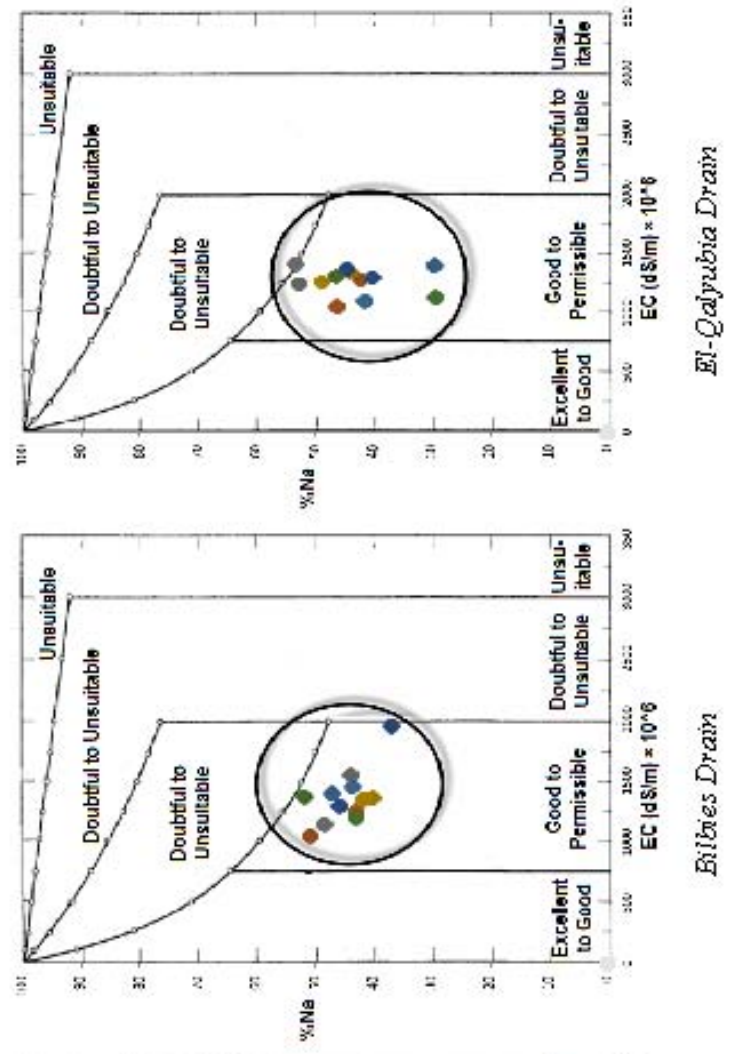

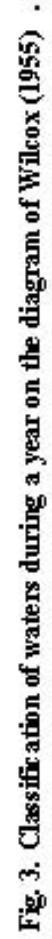

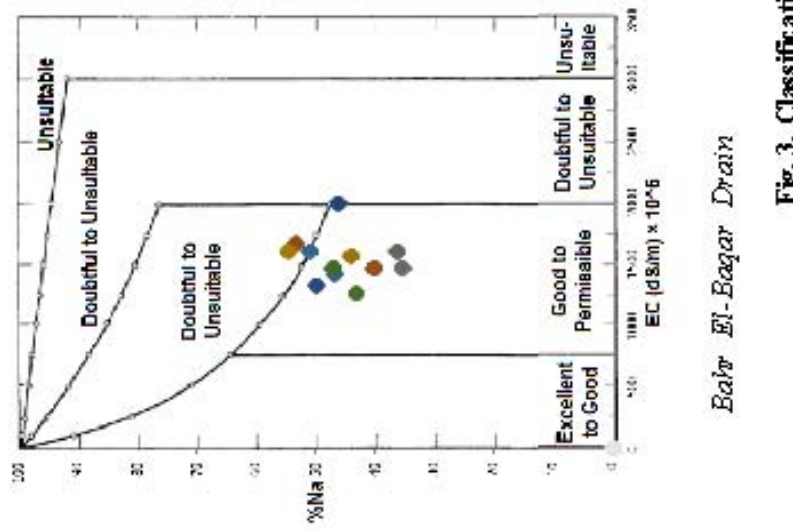

Egypt. J. Soil Sci. 55, No. 3 (2015) 

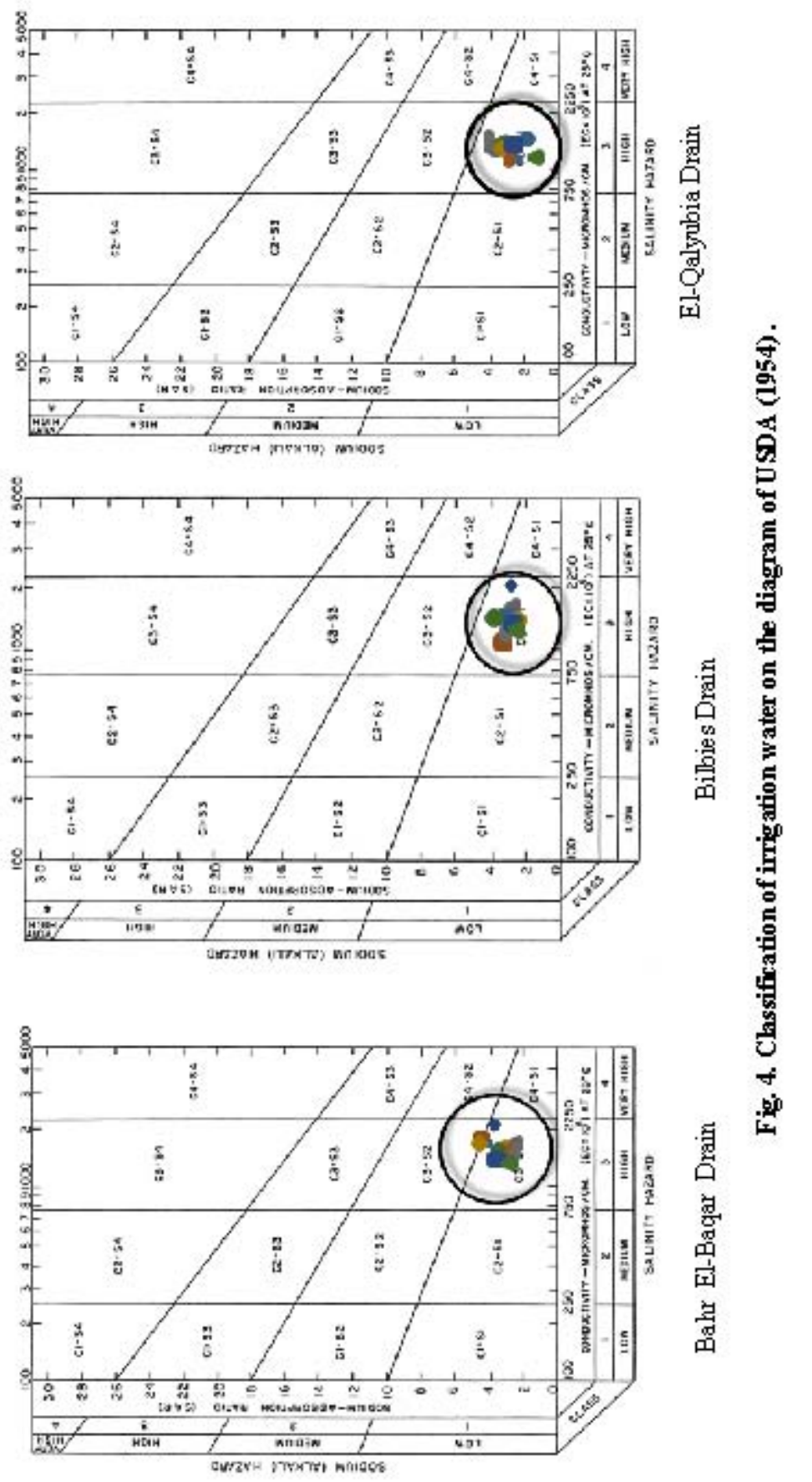

Egypt. J. Soil Sci. 55, No.3 (2015) 


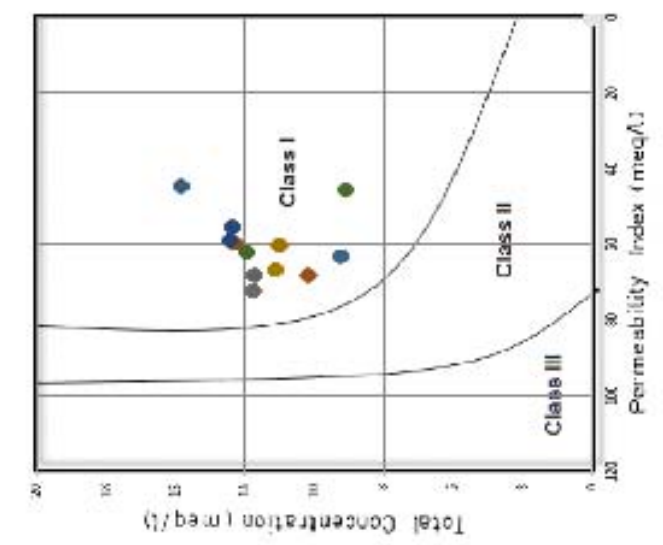

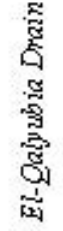

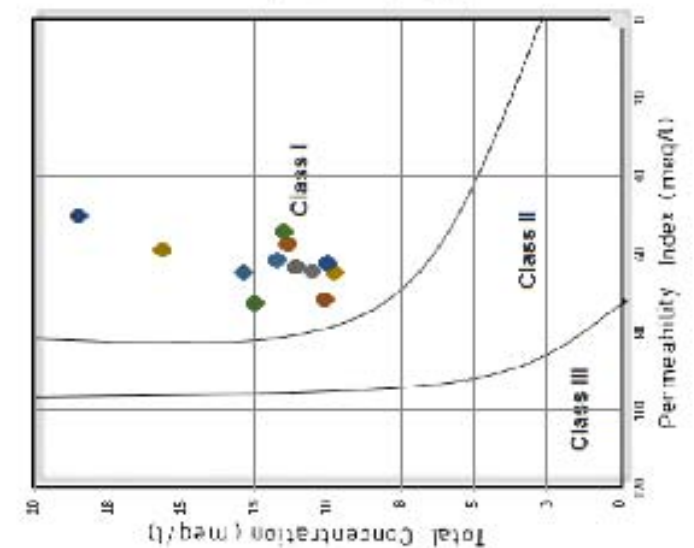



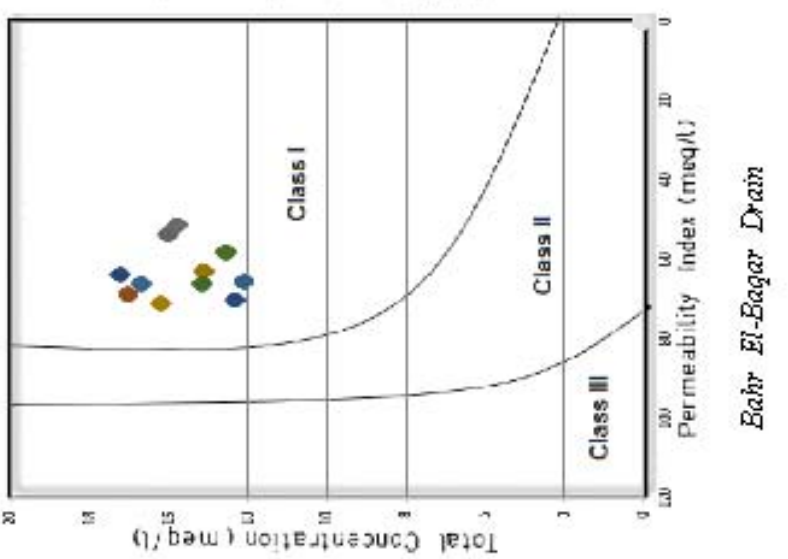


Kelly's index (KI)

According to the classification of KI, waters in three drains have KI of $<1.0$; therefore, they could be used for irrigation.

Magnesium adsorption ratio (MAR)

MAR values were 41.65, 30.52 and 41.20 for Bahr El-Baqar, Bilbies and ElQalyubia drains, respectively. Therefore, the water is suitable for use in irrigation since the values are $<50$ in waters of the three drains.

\section{Conclusion}

Drainage waters of Bahr El-Baqar Drain, Bilbies and El-Qalyubia Drains are classified as class high salinity low sodicity hazard (C3S1) according to USDA (1954) and could be used on soils with some precautions. Even with adequate drainage, special management for salinity control may be required and plants with good tolerance should be selected. According to Gupta classification, Bahr El-Baqar water is classified of low salinity with non-sodic hazard (C2S0) while waters of Bilbies and El-Qalyubia Drains are normal water with non-sodic hazard (C1S0) and can be used for irrigation with most crops on most soils. Most of the crops except sensitive ones comprising some horticultural and leguminous plants can be grown on all soils except very heavy textured, with impeded drainage. Waters of the three drains do not have any sodicity hazard problem.

Acknowledgments: Sincere thanks and appreciation are due to Professor Dr. Khalid G. Soliman, Professor of Soils, Faculty of Agriculture, Zagazig University, Egypt for his valuable guidance through this investigation.

\section{References}

Abdel-Shafy, H.I. and Aly, R.O. (2002) Water issue in Egypt resources, pollution and protection endeavors. Central European J. Occupational and Environmental Medicine, 8 (1), 3-21.

Abu, Z.M. (2011) Egyptian policies for using low quality water for irrigation. Wat. Res. Center, Cairo, Egypt.

Al-Amry, A.S. (2008) Hydro geochemistry and groundwater quality assessment in an Arid Region: A case study from al salameh area, Shabwah, Yemen. The $3^{\text {rd }}$ International Conference on Water Resources and Arid Environments (2008) and the $1^{\text {st }}$ Arab Water Forum.

Ali, O.M., El-Sikhry E.M. and El-Farghal, W.M. (1993) Effect of prolonged use of Bahr El-Baqar drain water for irrigation on the total heavy metals content of south Port Said soils. Proc. $1^{\text {st }}$. Conf. Egypt. Hung. Environ. Egypt.

APHA. (1995) "Standard Methods of Analysis of Water and Waste Water" (19 $9^{\text {th }}$ ed.), American Public Health Association, Washington D.C. 
Da Costa, A.C.A., Mesquita, L.M.S. and Tornovsky, J. (1996) Batch and continuous heavy metals biosorption by brown seaweed from a zinc producing plant. Minerals Eng. 9 (8), 811-824.

Doneen, L.D. (1962) The influence of crop and soil on percolating water. In: Proc. 1961 Bi-annual Conference on Groundwater Recharge, pp.156-163.

Doneen, L.D. (1964) Notes on water quality in agriculture. Water Sci. and Eng: Paper No. 4001, Dept. of Water Sci. and Engg., Univ. of California, Davis. USA.

DRI (2005) “Annual Drainage Water Quality Monitoring for the Year 2005”. Egyptian Drainage Research Institute Handbook for 2005.

Ezzat, A.I. (1989) Studies on phytoplankton in some polluted areas of Lake Manzala. Bull. Nat. Inst. Ocean Fish, A.R.E. 15, 1-19.

FAO (1985) Guidelines: Land evaluation for irrigated agriculture - FAO Soils Bulletin 55. Food and Agriculture Organization (FAO) of the United Nations, Rome, Italy.

Fipps, G. (1998) "Irrigation Water Quality Standards and Salinity Management". The Texas A \& M University System.

Gupta, I.C. (1979a) "Use of Saline Water in Agriculture in Arid and Semi-arid Zones of India". Oxford and IBH publishing Co. Pvt Ltd., New Delhi, India.

Gupta, I.C. (1979b) Note on the effect of leaching and gypsum on the detoxification of Boron in saline-sodic soils. Current Agri. 4, 51-55.

Gupta, I.C. (1990) Use of Saline Water in Agriculture: A Study of Arid and Semi-arid Zones of India. New Delhi: Oxford and IBH Publications.

Hem, J.D. (1985) "Study and Interpretation of the Chemical Characteristics of Natural Water", $3^{\text {rd }}$ ed. Scientific Publishers, Jodhpur, India.

Kelly, W.P. (1940) Permissible composition and concentration of irrigation water. Proc. Amer. Soc. Civ. Engin. 66, pp.607-613

Khalil, M.T. (1985) The effect of sewage and pollutional wastes upon Bahr El-Baqar drain and the southern area of Lake Manzala, Egypt. Egypt. J. Wil Nat. Resourc. 6,162-171.

Kumar, M., Kumari, K., Ramanathan, A.L. and Saxena, R. (2007) A comparative evaluation of groundwater suitability for irrigation and drinking purposes in two intensively cultivated districts of Punjab. India. Environ. Geol. 53, 553-574.

Paliwal, K.V. (1972) Irrigation with saline water, Monogram No. 2 (Newseries). New Delhi, IARI.

Park, J.H. and Shin, W.S. (2006) Immobilization of Pb contaminated soil using modified clay. Water Practice Technol. 1, 1-10.

Egypt. J. Soil Sci. 55, No. 3 (2015) 
Pipper, A.M. (1944) A graphic procedure in geochemical interpretation of water analyses. Trans. Am. Geophys. Union, 25, $914-923$.

Rashed, I.G. and Holmes, P.G. (1984) Chemical survey of Bahr El Bakar drain system and its effects on Manzala Lake. In: Proceedings of the $2^{\text {nd }}$ Egyptian Congress of Chemical Engineering. Cairo, Egypt, March $18^{\text {th }}-20^{\text {th }}, 1984$.

Saad, A.K. (1997) Environmental hydrogeologic impacts of groundwater withdrawal in the eastern Nile Delta region with emphasis on groundwater pollution potential. $P h$. D. Thesis, Institute of Environmental Studies. Ain Shams Univ. Cairo, Egypt.

Sundaray, S.K., Nayak, B.B. and Bhatta, D. (2009) Environmental studies on river water quality with reference to suitability for agricultural purposes: Mahanadi river estuarine system, India - a case study. Environ. Monitor. Assess 155, 227-243.

Taha, A.A., El-Mahmoudi, A.S. and El-Haddad, I.M. (2004) Pollution sources and related environmental impacts in the new communities southeast Nile delta, Egypt. Emirates J. Eng. Res. 9 (1), 35-49.

Todd, D.K. (1980) “Ground Water Hydrology”. Wiley, New York, USA.

UNEP/GEMS. (1991) Water pollution, United Nations Environment Program (UNEP)Glottal Education Management system (GEMS) Environmental Library 6.

USDA (1954) "Diagnosis and Improvement of Saline and Alkali Soils". Agriculture Handbook 60, US Gov. Printing Office, Washington, DC, USA.

Wilcox, L.V. (1955) "Classification and Use of Irrigation Waters". USDA, Circular 969, Washington, DC, USA.

(Received: 26/11/2014;

accepted:30/1/2015) 


\section{تقييم نوعية المياه العادمة لمصارف بحر البقر، القليوبية ويلبيس

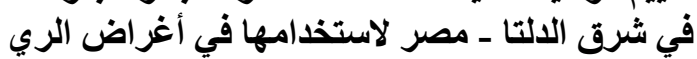

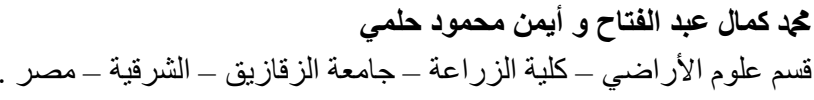

تم تجميع عينات مياه شهريا من مصارف القليوبية وبلييس وبحر البقر و الموجودة

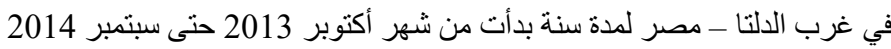

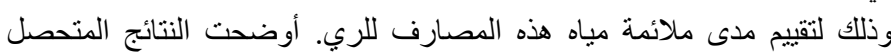

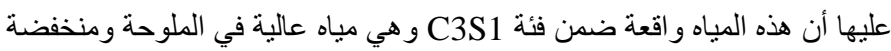

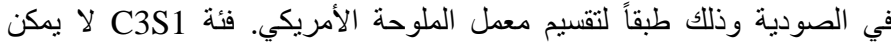

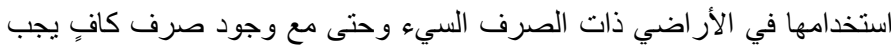

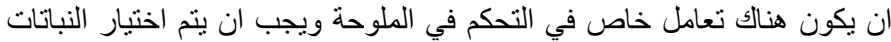

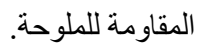

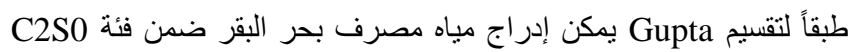

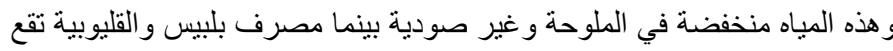

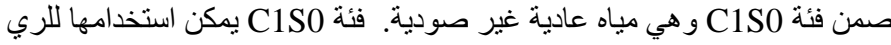

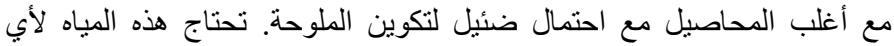

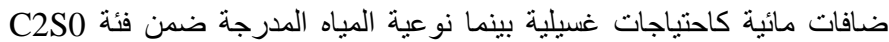
يمكن استخدامها في حالة حدوث غسيل بكميات معتدلة أثناء عمليات الرئ الري. 